\title{
Magnetic nanoparticles as a support for a copper (II) complex with nuclease activity
}

\author{
Maria A.S. Silva ${ }^{a}$, Adolfo I.B. Romo ${ }^{a}$, Dieric S. Abreu ${ }^{a}$, Marta S.P. Carepo ${ }^{\mathrm{a}, \mathrm{b}}$, Luis Lemus ${ }^{\mathrm{c}, *}$, \\ Miguel Jafelicci Jr. ${ }^{\mathrm{d}}$, Tércio F. Paulo ${ }^{\mathrm{a}}$, Otaciro R. Nascimento ${ }^{\mathrm{e}}$, Esteban Vargas, \\ Juliano C. Denardin $^{\mathrm{f}, \mathrm{g}}$, Izaura C.N. Diógenes ${ }^{\mathrm{a}, *}$ \\ a Departamento de Química Orgânica e Inorgânica, Universidade Federal do Ceará, Cx. Postal 6021, Fortaleza, CE 60451-970, Brazil \\ b UCIBIO, REQUIMTE, Departamento de Química, Faculdade de Ciências e Tecnologia, Universidade Nova de Lisboa, Caparica, Portugal \\ ${ }^{\mathrm{c}}$ Facultad de Química y Biología, Universidad de Santiago de Chile, Alameda 3363, Estación Central, Santiago, Chile \\ d Instituto de Química, Universidade Estadual Paulista (UNESP), Rua Prof. Francisco Degni, 55, Araraquara, SP 14801-060, Brazil \\ e Grupo de Biofísica Molecular Sérgio Mascarenhas, Departamento de Física e Ciências Interdisciplinares, Instituto de Física de São Carlos, Universidade de São Paulo, \\ Brazil \\ ${ }^{\mathrm{f}}$ Departamento de Física, Universidad de Santiago de Chile and CEDENNA, Av. Ecuador 3493, Santiago, Chile \\ ${ }^{g}$ Departamento de Física, Universidade Federal do Santa María, Santa María, RS 97105-900, Brazil
}

\section{A R T I C L E I N F O}

\section{Keywords:}

Core-shell magnetic nanoparticles

Copper complex

DNA nuclease activity

Reactive oxygen species

Hydroxyl radical

\begin{abstract}
A B S T R A C T
Magnetic nanoparticles have been extensively explored for the development of platforms for drug delivery and imaging probes. In this work, we have used a modular capping strategy to produce magnetic gold-coated $\mathrm{Fe}_{3} \mathrm{O}_{4}$ $\left(\mathrm{Fe}_{3} \mathrm{O}_{4} @ \mathrm{Au}\right)$ nanoparticles, which have been decorated with a copper (II) complex containing a thioether derivative of clip-phen $\left(\mathrm{Fe}_{3} \mathrm{O}_{4} @ \mathrm{Au} @ \mathrm{Cu}\right)$, where the complex $[\mathrm{Cu}(2 \mathrm{CP}-\mathrm{Bz}-\mathrm{SMe})]^{2+}$ has affinity to bind DNA and proven nuclease activity (2CP-Bz-SMe=1,3-bis((1,10-phenanthrolin-2-yl)oxy)- $N$-(4-(methylthio)benzylidene) propan-2-imine). The functionalization of $\mathrm{Fe}_{3} \mathrm{O}_{4} @ \mathrm{Au}$ with the copper complex occurs through the sulfur atom of the thioether moiety, as indicated by Raman scattering on surface. The magnetic measurements showed the nanomaterial $\mathrm{Fe}_{3} \mathrm{O}_{4} @ \mathrm{Au} @ \mathrm{Cu}$ is still magnetic although the gold shell and the functionalization with the copper complex have diminished the magnetization due to the dilution of the magnetic core. The nuclease assays performed with $\mathrm{Fe}_{3} \mathrm{O}_{4} @ \mathrm{Au} @ \mathrm{Cu}$ indicate that the nuclease activity of the nanomaterial toward the plasmid DNA involves an oxidative pathway in which $\mathrm{H}_{2} \mathrm{O}_{2}$ species is involved as intermediate in a Fenton-like reaction. Based on the electron paramagnetic resonance spectra $\left(\mathrm{a}^{\mathrm{N}}=15.07 \mathrm{G}, \mathrm{a}^{\mathrm{H}}=14.99 \mathrm{G}\right)$, such nuclease activity is assigned, essentially, to the $\mathrm{HO} \cdot$ species indicating that the radical production property of $[\mathrm{Cu}(2 \mathrm{CP}-\mathrm{Bz}-\mathrm{SMe})]^{2+}$ is successfully transferred to the core-shell gold-coated $\mathrm{Fe}_{3} \mathrm{O}_{4}$ magnetic nanoparticles. To the best of our knowledge, this is the first study reporting nuclease activity due to the reactive oxygen species generated by a copper complex immobilized on a gold-coated magnetic nanoparticle.
\end{abstract}

\section{Introduction}

Fundamental and frontier knowledge of physics and chemistry have been used in a joint effort to synthesize nanometer-sized structures for imaging and therapeutic applications. In this context, magnetic nanoparticles coated with gold in a sort of core@shell nanostructure have been of great interest. Besides the stability enhancement provided by the gold shell, the biocompatibility and the easiness of gold modification have offered a sophisticate and wide range of functionalization possibilities going from the attachment of simple oxides to more complex organic and/or inorganic molecules depending on the desired application [1, 2]. Furthermore, the advantage that core@shell magnetic nanostructures can be guided toward specific targets by a magnetic field gradient is a highly desirable property, especially in biomedical applications [3, 4]. Since the late 1970s when Widder et al. [5] proposed the term "magnetic drug delivery" for magnetic nanoparticles functionalized with drug molecules, tens of thousands of publications can be found in the literature aiming, mainly, to reduce toxicity and adverse side-effects. In addition, a selective drug delivery platform would present a stimuli-responsive behavior for on-demand dosing. Currently, chemotherapy treatments are based on drug-DNA associations due to the role DNA plays at cellular level in the cell replication

\footnotetext{
* Corresponding author.

E-mail addresses: luis.lemus@usach.cl (L. Lemus), izaura@dqoi.ufc.br (I.C.N. Diógenes).
} 
and differentiation processes. The interaction of a given drug with DNA, in turn, can occur through the major or minor grooves with the formation of covalent bonds or by DNA degradation by reactive oxygen species (ROS) [6-13]. Coordination compounds of $\mathrm{Cu}$ and $\mathrm{Mn}$ containing phenanthroline (phen) derived ligands have been extensively studied due to the ability to degrade DNA either by intercalation and/or oxidative mechanisms [13-18]. A series of copper complexes containing tetracoordinating bis-phenanthroline ligands, named clip-phen (1,3-bis((1,10-phenanthrolin-2-yl)oxy)propan-2-amine), was developed by Pitié et al. and showed antitumor properties [14, 19-22]. The clipphen compounds are able to intercalate with DNA and to form copper complexes with nuclease activity about 60 times higher than $[\mathrm{Cu}$ $\left.(\text { phen })_{2}\right]^{+}$through multi-steps mechanisms involving oxidative pathways [23-26]. The nature of these ROS species, however, and the formation of intermediates are still under debate.

In our group, we have deliberately attached a thioether fragment to a clip-phen derived ligand, thus producing the Schiff base ligand 1,3-bis (1,10-phenanthrolin-2-yloxy)- $N$-(4-(methylthio)benzylidene)propan-2imine (2CP-Bz-SMe) to coordinate copper ions and also modify gold substrates. The design of $[\mathrm{Cu}(2 \mathrm{CP}-\mathrm{Bz}-\mathrm{SMe})]^{2+}$ also took in account the positive net charge of the complex and the planarity of the phenanthroline moieties. While the latter feature favors the interaction with DNA through intercalation, the positive charge enhances the electrostatic attraction toward the polyanionic DNA. The inclusion of a complex into the topological domains of the double helix (intercalation or groove binding) is a desired condition for artificial nucleases operating via ROS generation, where the reactive hydroxyl radical (HO-) might be produced into close proximity with DNA thus causing damage. In addition, the inter-phenanthroline bridge in 2CP-Bz-SMe is flexible enough to stand the variations in the coordination geometry of the copper atom due to the changes in the oxidation states $\left(\mathrm{Cu}^{\mathrm{II}} / \mathrm{Cu}^{\mathrm{I}}\right)$ in a Fentonlike reaction (tetrahedral for $\mathrm{Cu}^{\mathrm{I}}$ and square-planar for $\mathrm{Cu}^{\mathrm{II}}$ ). The association between biochemical and electrochemical studies indicated that the ion complex $[\mathrm{Cu}(2 \mathrm{CP}-\mathrm{Bz}-\mathrm{SMe})]^{2+}$ indeed degrade DNA due to the generation of $\mathrm{HO}$ - through a mechanism involving a Fenton-like reaction [17].

Have proven the ability of $[\mathrm{Cu}(2 \mathrm{CP}-\mathrm{Bz}-\mathrm{SMe})]^{2+}$ to adsorb on gold solid substrate, this work intends to decorate magnetic core-shell goldcoated $\mathrm{Fe}_{3} \mathrm{O}_{4}$ nanoparticles $\left(\mathrm{Fe}_{3} \mathrm{O}_{4} @ \mathrm{Au}\right)$ with $[\mathrm{Cu}(2 \mathrm{CP}-\mathrm{Bz}-\mathrm{SMe})]^{2+}$ $\left(\mathrm{Fe}_{3} \mathrm{O}_{4} @ \mathrm{Au} @ \mathrm{Cu}\right)$ to investigate whether the copper complex retain its ability to generate $\mathrm{HO} \cdot$ upon the immobilization on the magnetic nanomaterial. Aiming to achieve this goal, a multidisciplinary effort is addressed connecting several techniques associated with material science, coordination chemistry and biochemistry. At first, the discussion will briefly focus on the functionalization of $\mathrm{Fe}_{3} \mathrm{O}_{4} @ \mathrm{Au}$ with $[\mathrm{Cu}(2 \mathrm{CP}$ $\mathrm{Bz}-\mathrm{SMe})]^{2+}$ thus forming $\mathrm{Fe}_{3} \mathrm{O}_{4} @ \mathrm{Au} @ \mathrm{Cu}$. Second, the magnetic properties determined from vibrating sample magnetometry (VSM) measurements of $\mathrm{Fe}_{3} \mathrm{O}_{4} @ \mathrm{Au} @ \mathrm{Cu}$ will be compared to the parent sample to show that the functionalized nanoparticles still exhibit magnetic behavior. Finally, as the main goal of this work, electrophoresis and electron paramagnetic resonance (EPR) data will be presented to discuss both the nuclease activity of $\mathrm{Fe}_{3} \mathrm{O}_{4} @ \mathrm{Au} @ \mathrm{Cu}$ and the generation of hydroxyl radical.

\section{Experimental section}

\subsection{Chemicals and procedures}

Deionized water (18.2 $\mathrm{M} \Omega \mathrm{cm}$ at $25^{\circ} \mathrm{C}$, Milli-Q) was used to prepare all aqueous solution. $\mathrm{KH}_{2} \mathrm{PO}_{4},(99 \%), \mathrm{K}_{2} \mathrm{HPO}_{4}(99 \%)$ were purchased from Sigma-Aldrich and used to prepare the phosphate buffer solution (PBS) in a $\mathrm{pH}$ range adjusted with $\mathrm{KOH}(98 \%$, Fisher Scientific) and $\mathrm{HCl}$ (99\%, Tedia). Iron(III) acetylacetonate, $\left[\mathrm{Fe}(\mathrm{acac})_{3}\right]$ (99.9\%), 1,2-dodecanediol (90\%), oleic acid (99\%), oleylamine (70\%) and benzyl ether (98\%), from Sigma-Aldrich, and gold acetate, $\mathrm{Au}\left(\mathrm{O}_{2} \mathrm{CCH}_{3}\right)_{3}(99.9 \%)$, from Alfa Aesar, were used without prior purification. 1,10- phenantroline, active neutral alumina (70-290 mesh), metallic sodium, 4-methylthio-benzaldehyde, 2-amino-1,3-propanediol, and deuterated tetrachloroethane $\left(\mathrm{C}_{2} \mathrm{D}_{2} \mathrm{Cl}_{4}\right)$ were purchased from Aldrich and used as received. $\mathrm{Cu}\left(\mathrm{NO}_{3}\right)_{2} \cdot 3 \mathrm{H}_{2} \mathrm{O}$, from Merck, was used without any treatment. Methanol and dimethylformamide were dried over $4 \AA$ A molecular sieves for $72 \mathrm{~h}$ prior to use. Acetonitrile (chromatographic grade, from Mallinckrodt) was dried by heating to reflux over $\mathrm{P}_{2} \mathrm{O}_{5}$. Plasmid pBR322 was purchased from New England BioLabs and used as received. Catalase from bovine liver, D-mannitol, and superoxide dismutase bovine erythrocyte, all from Sigma-Aldrich, were used as received in the DNA cleavage assays, which were acquired in $10 \mathrm{mM}$ PBS, $\mathrm{pH}$ 7.4. All other chemicals were of at least reagent grade quality and were used as received.

The Schiff base ligand 1,3-bis((1,10-phenanthrolin-2-yl)oxy)- $\mathrm{N}$-(4(methylthio)benzylidene)propan-2-imine (2CP-Bz-Me) and the $[\mathrm{Cu}$ (2CP-Bz-SMe)] $\left(\mathrm{NO}_{3}\right)_{2}$ complex were synthesized as previously described in the literature [17].

\subsubsection{Synthesis of $\mathrm{Fe}_{3} \mathrm{O}_{4} @ \mathrm{Au} \mathrm{NPs}$}

$\mathrm{Fe}_{3} \mathrm{O}_{4} @ \mathrm{Au}$ core-shell nanoparticles were synthesized by seedmediated growth approach, where $\mathrm{Fe}_{3} \mathrm{O}_{4}$ nanoparticles are employed as seeds for the subsequent gold coating in a two-step procedure following a protocol adapted from the literature [27]. First, $\mathrm{Fe}_{3} \mathrm{O}_{4} \mathrm{NPs}(c a .6 \mathrm{~nm})$ were prepared according to the reported method [28]. Subsequently, the gold shell was grown on $\mathrm{Fe}_{3} \mathrm{O}_{4}$ (hexane suspension) by chemical reduction of $\mathrm{Au}\left(\mathrm{O}_{2} \mathrm{CCH}_{3}\right)_{3}$ with 1,2-dodecanediol in the presence of oleic acid, oleylamine and benzyl ether, under argon flow, using different $\mathrm{Fe}_{3} \mathrm{O}_{4}$ : $\left[\mathrm{Au}\left(\mathrm{O}_{2} \mathrm{CCH}_{3}\right)_{3}\right]$ molar ratios (1:1, 1:2 and 1:3). The reaction mixture was heated up to $190^{\circ} \mathrm{C}\left(\right.$ rate $\left.1{ }^{\circ} \mathrm{C} / \mathrm{min}\right)$ and kept at this temperature for $1.5 \mathrm{~h}$ before cooled down to room temperature. The process, as well as the Transmission Electron Microscopy (TEM) images along with the respective particle size distribution histograms (for 1:3 ratio), are shown in Fig. S1 of the Electronic Supporting Information (ESI). Fig. S2 of the ESI shows the standard XRD patterns for $\mathrm{Fe}_{3} \mathrm{O}_{4}$ and $\mathrm{Au}$ in conjunction with those obtained for $\mathrm{Fe}_{3} \mathrm{O}_{4} @ \mathrm{Au}$ produced by mixing $\mathrm{Fe}_{3} \mathrm{O}_{4}$ with gold acetate in different molar ratios; all the samples exhibited diffraction peaks consistent with a gold face-centered cubic (fcc) phase. The XRD patterns showed a dependence on the amount of gold acetate going from the coexistence of both $\mathrm{Fe}_{3} \mathrm{O}_{4}$ and $\mathrm{Au}$ phases to no peak assigned to $\mathrm{Fe}_{3} \mathrm{O}_{4}$ phase in the $1: 3$ molar ratio.

\subsubsection{Functionalization of $\mathrm{Fe}_{3} \mathrm{O}_{4} @ A u N P s$}

The surface functionalization of $\mathrm{Fe}_{3} \mathrm{O}_{4} @ \mathrm{Au}$ NPs (1:3 molar ratio) with $[\mathrm{Cu}(2 \mathrm{CP}-\mathrm{Bz}-\mathrm{SMe})]^{2+}$ complex ions was carried out by means of place-exchange method in which magnetic NPs originally dispersed in organic medium can be transferred to an aqueous medium [29]. In this case, the direct replacement of the capping agents (oleic acid and oleylamine) by $[\mathrm{Cu}(2 \mathrm{CP}-\mathrm{Bz}-\mathrm{SMe})]^{2+}$ occurs due to the strong gold-sulfur bonding. In a typical procedure, $[\mathrm{Cu}(2 \mathrm{CP}-\mathrm{Bz}-\mathrm{SMe})]^{2+}$ methanol solution ( $5 \mathrm{~mL}, 2.4 \mathrm{mg} \mathrm{mL}^{-1}$ ) was slowly added to the hydrophobic $\mathrm{Fe}_{3} \mathrm{O}_{4} @ A u$ NPs hexane suspension $\left(10 \mathrm{~mL}, 2.3 \mathrm{mg} \mathrm{mL}^{-1}\right)$ into the $50 \mathrm{~mL}$ centrifuge tube, under argon flow. The biphasic mixture was placed in a water bath ultrasonicator for $20 \mathrm{~min}$ and then it was vigorously stirred $(170 \mathrm{rpm})$ at room temperature for $24 \mathrm{~h}$. The $\mathrm{Fe}_{3} \mathrm{O}_{4} @ \mathrm{Au} @ \mathrm{Cu}$ NPs were separated by centrifugation at $6000 \mathrm{rpm}$ for $20 \mathrm{~min}$. The precipitated product was firstly rinsed with hexane to remove the capping agents and, subsequently, with methanol and water to remove the non-immobilized $[\mathrm{Cu}(2 \mathrm{CP}-\mathrm{Bz}-\mathrm{SMe})]^{2+}$ species. The washing process was repeated until the supernatant was clear and the UV-vis spectrum presented no absorption bands that could be assigned to the complex. At each washing step, the particle suspension was vortexed ( $5 \mathrm{~min}$ ) and centrifuged ( $6000 \mathrm{rpm}$ for $20 \mathrm{~min}$ ). The successful functionalization of $\mathrm{Fe}_{3} \mathrm{O}_{4} @ \mathrm{Au}$ was visually indicated by obtaining a blue suspension in water. Each step of the production of the core-shell gold-coated $\mathrm{Fe}_{3} \mathrm{O}_{4}$ nanoparticles decorated with $[\mathrm{Cu}(2 \mathrm{CP}-\mathrm{Bz}-\mathrm{SMe})]^{2+}$ was followed by TEM (see Fig. S1 of the ESI). As can be ascertained 
from the histograms, the gold coating of $\mathrm{Fe}_{3} \mathrm{O}_{4}$ nanoparticles implies an average size increase from $6.4 \pm 0.7$ to $8.6 \pm 1.8 \mathrm{~nm}$, no further size increase is observed upon the immobilization of the copper complex.

\subsubsection{Plasmid pBR322 cleavage assays}

Reactions using supercoiled plasmid pBR322 (BioLabs) were performed in $22 \mu \mathrm{L}$ of $10 \mathrm{mM}$ phosphate buffer solution $\mathrm{pH}$ 7.4. The DNA and $\mathrm{Fe}_{3} \mathrm{O}_{4} @ \mathrm{Au} @ \mathrm{Cu}$ concentrations were kept constant for all reactions at $6.8 \mathrm{ng} \mathrm{mL}^{-1}$ and $0.807 \mathrm{mg} \mathrm{mL}^{-1}$, respectively. A final concentration of $15 \mu \mathrm{M}$ for ascorbic acid was used for the reactions containing this reagent. Scavengers, catalase $\left(100 \mu \mathrm{gL}^{-1}\right)$, D-mannitol $(50 \mathrm{mM})$, and superoxide dismutase (SOD) $\left(100 \mu \mathrm{g} \mathrm{mL}^{-1}\right)$, were used in separate reactions containing the plasmid pBR322, $\mathrm{Fe}_{3} \mathrm{O}_{4} @ \mathrm{Au} @ \mathrm{Cu}$ and ascorbic acid, aiming to identify the nature of the generated reactive oxygen species (ROS). $\mathrm{H}_{2} \mathrm{O}_{2}$ (3 mM final concentration) was also incubated with $\mathrm{Fe}_{3} \mathrm{O}_{4} @ \mathrm{Au} @ \mathrm{Cu}$ and DNA in the absence of reducing agents as well as in the presence of D-mannitol $(50 \mathrm{mM})$. All reactions were incubated for $30 \mathrm{~min}$ at room temperature. Following the incubation, $4 \mathrm{~mL}$ of $6 \times$ DNA loading dye (Biolabs) were added to the reaction mixture and the samples were immediately loaded on a $0.8 \%$ agarose gel in TEA buffer pH 8.0 (40 mM，2-amino-2-hydroxymethyl-propane-1,3-diol, $20 \mathrm{mM}$ acetic acid, $1 \mathrm{mM}$ EDTA) and electrophoresed in a horizontal electrophoresis system (Bio-Rad) at $70 \mathrm{~V}$. After electrophoresis, the gels were stained with GelRedTM (Biotium, Inc.) for $30 \mathrm{~min}$ and the images were acquired with a Gel Doc XR + system (Bio-Rad) using the Quantity One 1D analysis software.

\subsubsection{EPR measurements}

To an aerated aqueous suspension containing $\mathrm{Fe}_{3} \mathrm{O}_{4} @ \mathrm{Au} @ \mathrm{Cu}, \mathrm{H}_{2} \mathrm{O}_{2}$ was added to a final concentration of $30 \mu \mathrm{M}$ and allowed to react for 2 min with previous addition of DMPO (5,5-Dimethyl-1-pyrroline- $N$ oxide, final concentration of $100 \mu \mathrm{M})$. The reaction mixture was centrifuged at $5000 \mathrm{rpm}$ for $2 \mathrm{~min}$ and a $150 \mu \mathrm{L}$ aliquot was extracted and transferred to the quartz cell of the EPR equipment.

\subsection{Apparatus}

X-ray powder diffraction (XRD) characterization was carried out on a Rigaku Rotaflex RU - 200B X-ray diffractometer with CuKa radiation $(\lambda=1.5418 \AA)$ in the $2 \theta$ range from 30 to $90^{\circ}$. Transmission Electron Microscopy (TEM) micrographs were taken using a HITACHI HT7700 transmission electron microscope operating at $120 \mathrm{kV}$. Samples were prepared for TEM analysis by dropping NPs suspensions onto carboncoated copper grids (300-mesh) followed by drying at room temperature. Size analysis was performed on captured digital images using ImageJ $1.45 \mathrm{~s}$ software. For each sample, the average particle size and size distribution was calculated from the diameters of at least 100 particles randomly selected from the TEM micrographs. The chemical composition was investigated by scanning electron microscopy with energy-dispersive X-ray spectroscopy (SEM-EDS) using a Quanta 450 FEG-FEI scanning electron microscope equipped with an EDS Bruker QUANTAX system coupled to the SEM microscope, using an acceleration voltage of $20 \mathrm{kV}$. The SEM-EDS analysis was performed on the powder samples mounted on the aluminum pin stubs using carbon conductive tapes and without the sputtering of another material. The $\mathrm{Fe}, \mathrm{Au}$ and $\mathrm{Cu}$ contents were determined by inductively coupled plasma with optical emission spectroscopy (ICP-OES) by using a Spectro Arcos spectrometer. Previously, the NPs samples were digested in concentrated aqua regia at $50^{\circ} \mathrm{C}$, and then diluted with Milli-Q water. The magnetic properties of the NPs samples were measured using a vibrating sample magnetometer (5 T-VSM from Cryogenic Ltd.) with a maximum applied field of $50 \mathrm{kOe}$ and a temperature range of 5 to $300 \mathrm{~K}$. Magnetization values were normalized and reported as emu per gram of sample. Electronic spectra in the ultraviolet and visible (UV-Vis) regions were acquired using a Cary 5000 UV/vis/NIR spectrophotometer. Normal Raman and Surface-Enhanced Raman Scattering (SERS) spectra were acquired on a Renishaw inVia confocal Raman system (controlled by WiRE 3.4 software) coupled to a Leica DM 500 microscope. The spectrometer was equipped with $785 \mathrm{~nm}$ diode laser $(300 \mathrm{~mW})$ with a spectral resolution of $\sim 1 \mathrm{~cm}^{-1}$. A $50 \times$ objective lens $(\sim 1 \mu \mathrm{m}$ laser spot size) was used to focus the laser beam and to collect the Raman signal. EPR measurements were carried out on a Varian E-109 spectrometer operating at the X-band. Measurement conditions: center field $339 \mathrm{mT}$, sweep field $10 \mathrm{mT}$, sweep time $60 \mathrm{~s}$, MW power $20 \mathrm{~mW}$, gain $2.0 \times 10^{3}$, modulation amplitude $0.05 \mathrm{mT}$, modulation frequency $100 \mathrm{kHz}$, time constant: $0.064 \mathrm{~s}$, MW frequency: $9.50390 \mathrm{GHz}$. Spectral simulations from which the hyperfine coupling constants were obtained were performed by using the EasySpin program [30].

\section{Results and discussion}

The incorporation of $[\mathrm{Cu}(2 \mathrm{CP}-\mathrm{Bz}-\mathrm{SMe})]^{2+}$ onto $\mathrm{Fe}_{3} \mathrm{O}_{4} @ \mathrm{Au}$ was achieved by place-exchange method in which the magnetic core $\mathrm{Fe}_{3} \mathrm{O}_{4}$ is firstly recovered with a gold shell which, in turn, is functionalized with the molecules of the copper complexes. Both the steps of the formation of the gold shell and the functionalization with the complex were performed by the displacement of the surfactant molecules, as illustrated in Scheme 1.

As a consequence of the functionalization with the hydrophilic charged $\mathrm{Cu}(\mathrm{II})$ complex, it was observed a decrease in the hydrophobicity of $\mathrm{Fe}_{3} \mathrm{O}_{4} @ \mathrm{Au}$ that made possible the dispersion of the nanomaterial in water. SEM-EDS analysis (Fig. S3(A) of the ESI) show emission peaks assigned to $\mathrm{O}, \mathrm{Fe}, \mathrm{Au}$ and $\mathrm{Cu}$ elements indicating the incorporation of the copper complex on $\mathrm{Fe}_{3} \mathrm{O}_{4} @ \mathrm{Au}$, based on the assumption that $[\mathrm{Cu}(2 \mathrm{CP}-\mathrm{Bz}-\mathrm{SMe})]^{2+}$ is the only source of $\mathrm{Cu}$ atoms. The

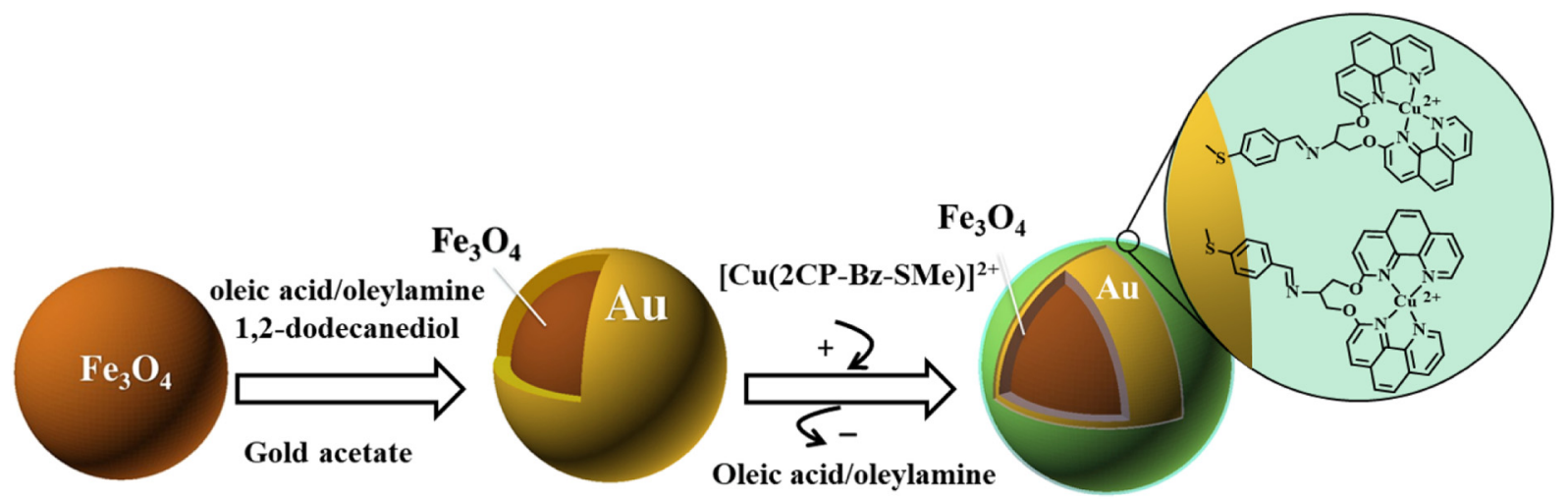

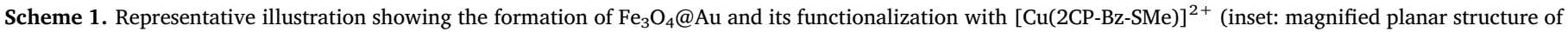
the complex). Images are out of scale. 

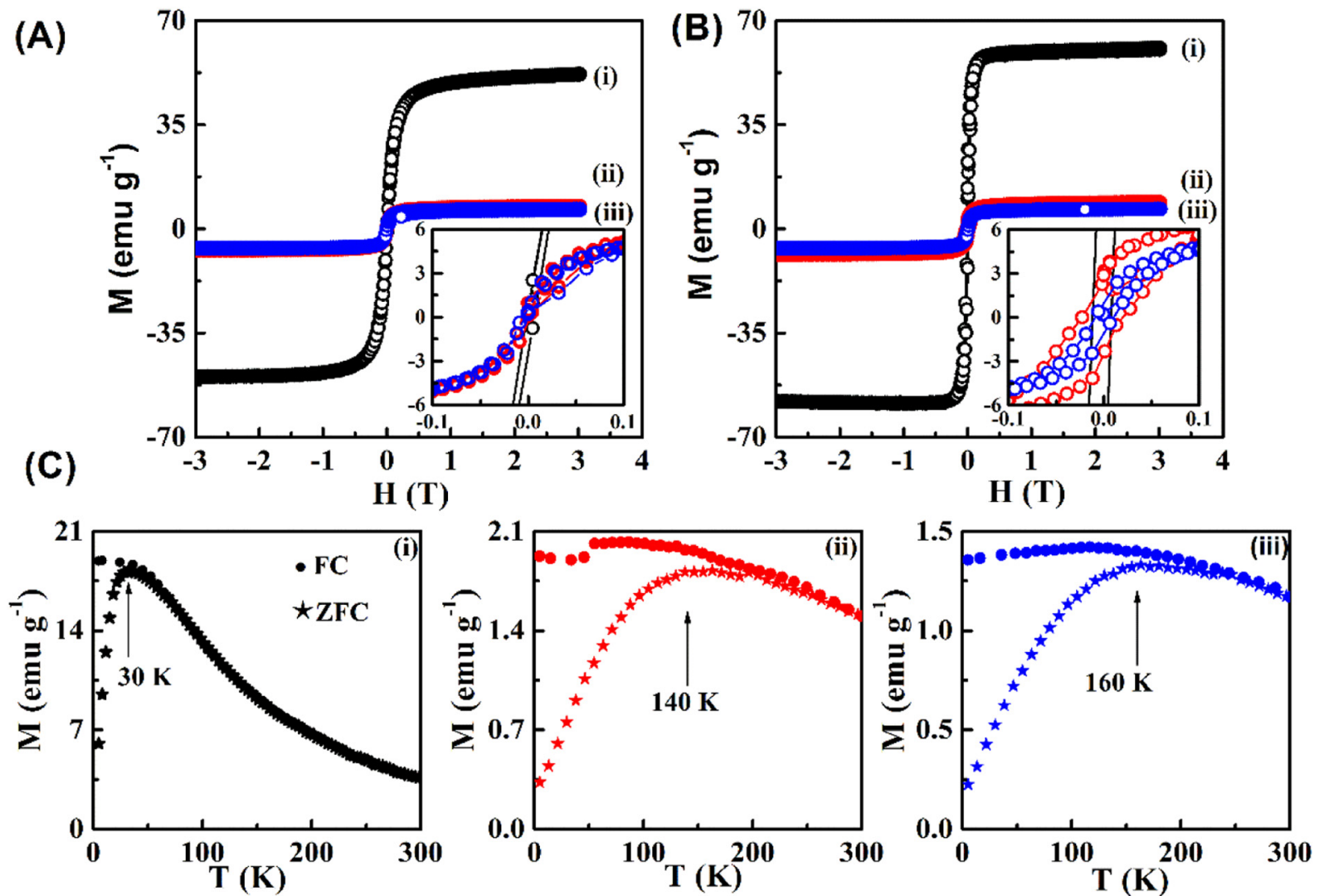

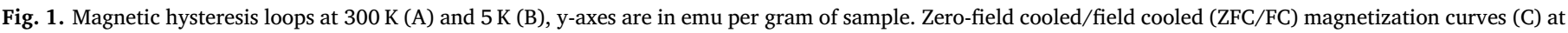

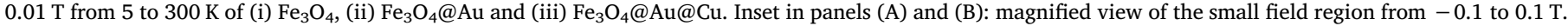

corresponding elemental mapping (Fig. S3(B) of the ESI) indicates the $\mathrm{O}, \mathrm{Fe}, \mathrm{Au}$ and $\mathrm{Cu}$ signatures of the functionalized core-shell structure and, also, the homogeneous distribution of the complex meaning the different phases are coexisting on the selected area of $\mathrm{Fe}_{3} \mathrm{O}_{4} @ \mathrm{Au} @ \mathrm{Cu}$ shown in the SEM image. The presence of the elements Fe $\left(5.69 \mathrm{mg} \mathrm{L}^{-1}\right.$, $7.11 \mathrm{wt} \%), \mathrm{Au}$ (59.50 $\left.\mathrm{mg} \mathrm{L}^{-1}, 74.38 \mathrm{wt} \%\right)$, and $\mathrm{Cu}\left(0.22 \mathrm{mg} \mathrm{L}^{-1}\right.$, $0.28 \mathrm{wt} \%)$ was confirmed by ICP-OES analysis after aqua regia digestion of $\mathrm{Fe}_{3} \mathrm{O}_{4} @ \mathrm{Au} @ \mathrm{Cu}$. Accordingly, the corresponding copper loading was found to be $43.28 \mu \mathrm{mol} \mathrm{g}^{-1}$.

The magnetic properties of the core-shell and functionalized nanoparticles were determined from VSM experiments and compared with those of the $\mathrm{Fe}_{3} \mathrm{O}_{4}$ parent sample. Fig. 1 shows the magnetization in function of the applied magnetic field and the dependence of the magnetic susceptibility on the temperature.

In comparison to $\mathrm{Fe}_{3} \mathrm{O}_{4}(52 \mathrm{emu} / \mathrm{g})$, the drastic reduction of the saturation magnetization $\left(\mathrm{M}_{\mathrm{s}}\right)$ observed for $\mathrm{Fe}_{3} \mathrm{O}_{4} @ \mathrm{Au}(8 \mathrm{emu} / \mathrm{g})$ and $\mathrm{Fe}_{3} \mathrm{O}_{4} @ \mathrm{Au} @ \mathrm{Cu}(6 \mathrm{emu} / \mathrm{g})$ in the magnetic hysteresis curves at $300 \mathrm{~K}$ is assigned to the dilution effect due to the incorporation of the nonmagnetic masses of the Au shell and copper complex. Near the zeromagnetization region (inset in Fig. 1A) it can be seen all samples present superparamagnetic state at room temperature. On the other hand, at $5 \mathrm{~K}$, all samples present a hysteretic behavior (inset in Fig. 1B) indicating the nanoparticles are blocked at low temperatures. The increase observed for the $M_{S}$ values at $5 \mathrm{~K}$, in comparison to that at $300 \mathrm{~K}$, is assigned to a more ordered spin structure due to the relative low thermal fluctuation and an enhancement of the magnetic anisotropy [31]. Table 1 summarizes the magnetic properties obtained for the nanoparticles studied in this work.

Fig. $1 \mathrm{C}$ shows the temperature dependence of magnetization measured at $0.01 \mathrm{~T}$ in ZFC (zero-field cooled) and FC (field cooled) modes from 5 to $300 \mathrm{~K}$. The average blocking temperatures $\left(\mathrm{T}_{\mathrm{B}}\right)$ values, which correspond to the temperature that separates the unblocked from
Table 1

Magnetic properties determined for $\mathrm{Fe}_{3} \mathrm{O}_{4}, \mathrm{Fe}_{3} \mathrm{O}_{4} @ \mathrm{Au}$ and $\mathrm{Fe}_{3} \mathrm{O}_{4} @ \mathrm{Au} @ \mathrm{Cu}$ at 300 and $5 \mathrm{~K}$.

\begin{tabular}{llllll}
\hline Sample & \multicolumn{4}{l}{ Magnetic properties } \\
\cline { 2 - 6 } & $\mathrm{T}_{\mathrm{B}}(\mathrm{K})$ & $\mathrm{M}_{\mathrm{S}}{ }^{300 \mathrm{~K}}(\mathrm{emu} / \mathrm{g})$ & $\mathrm{M}_{\mathrm{S}}{ }^{5 \mathrm{~K}}(\mathrm{emu} / \mathrm{g})$ & $\mathrm{H}_{\mathrm{C}}{ }^{300 \mathrm{~K}}(\mathrm{~T})$ & $\mathrm{H}_{\mathrm{C}}{ }^{5 \mathrm{~K}}(\mathrm{~T})$ \\
\hline $\mathrm{Fe}_{3} \mathrm{O}_{4}$ & 30 & 52 & 60.82 & 0.0039 & 0.0098 \\
$\mathrm{Fe}_{3} \mathrm{O}_{4} @ \mathrm{Au}$ & 140 & 8 & 8.95 & 0.0038 & 0.0212 \\
$\mathrm{Fe}_{3} \mathrm{O}_{4} @ \mathrm{Au} @ \mathrm{Cu}$ & 160 & 6 & 6.44 & 0.0039 & 0.0096 \\
\hline
\end{tabular}

the blocked state, were measured from the maximum of the ZFC magnetization curve. $\mathrm{T}_{\mathrm{B}}$ values were observed at 30,140 and $160 \mathrm{~K}$ for $\mathrm{Fe}_{3} \mathrm{O}_{4}, \mathrm{Fe}_{3} \mathrm{O}_{4} @ \mathrm{Au}$ and $\mathrm{Fe}_{3} \mathrm{O}_{4} @ \mathrm{Au} @ \mathrm{Cu}$, respectively. At high temperatures, above $\mathrm{T}_{\mathrm{B}}$, the unblocked state can be seen while below $\mathrm{T}_{\mathrm{B}}$, all samples are in the blocked state behaving like conventional ferromagnetic materials, in accordance with the hysteresis loops.

The increase in $\mathrm{T}_{\mathrm{B}}$ observed for $\mathrm{Fe}_{3} \mathrm{O}_{4} @ \mathrm{Au}$ and $\mathrm{Fe}_{3} \mathrm{O}_{4} @ \mathrm{Au} @ \mathrm{Cu}$ is assigned to the increase of the coupling of the magnetic dipole moments of the magnetic cores of neighboring nanoparticles [32]. Such effect is likely due to the decrease of the inter-particle spacing. We hypothesize two factors may explain such effect in the inter-particle distance: (i) the replacement of the surfactant species $(\sim 30 \AA)$ by the smaller molecules of the copper complex $(\sim 15 \AA)$; (ii) the possible formation of polynuclear interconnection among the complexes of neighboring functionalized nanoparticles.

The UV-Vis spectrum of $\mathrm{Fe}_{3} \mathrm{O}_{4} @ \mathrm{Au} @ \mathrm{Cu}$ (Fig. S4 of the ESI) presents the characteristic bands of the copper complex assigned to the intraligand $\pi^{*} \leftarrow \pi$ transitions of 2CP-Bz-SMe [33], in the region from 250 to $450 \mathrm{~nm}$. A broad band assigned to the surface plasmon (SP) absorption of gold is observed with maximum at $620 \mathrm{~nm}$ indicating the immobilization of the copper complex on $\mathrm{Fe}_{3} \mathrm{O}_{4} @ \mathrm{Au}$. The SP absorption 
presents a red shift in comparison to the spectrum of $\mathrm{Fe}_{3} \mathrm{O}_{4} @ \mathrm{Au}$ $(\lambda=525 \mathrm{~nm})$ indicating spatial closeness after the immobilization of the copper complex. This result is in agreement with the decrease in the inter-particle spacing, since it enhances the coupling of the localized surface plasmons implying a red shift of the SP band [34]. The SERS spectra obtained for $\mathrm{Fe}_{3} \mathrm{O}_{4} @ \mathrm{Au} @ \mathrm{Cu}$ (Fig. S4 of the ESI) presents, as the most intense peak, the stretching mode assigned to the CS bond at $724 \mathrm{~cm}^{-1}$ [35-37], indicating the gold-coated $\mathrm{Fe}_{3} \mathrm{O}_{4}$ nanoparticles was successfully modified with the copper complex via the sulfur atom of the thioether moiety; a result that was indeed expected due to the known affinity between gold and sulfur atoms [17, 38-41].

Despite the extremely restrained diffusion of $\mathrm{HO}$ - radical in physiological medium (no longer than $50 \AA$ ) [42], nuclease assays have shown that the reduction of $[\mathrm{Cu}(2 \mathrm{CP}-\mathrm{Bz}-\mathrm{SMe})]^{2+}$ in the presence of dioxygen induces the degradation of DNA due to the generation of $\mathrm{HO}$ [17]. Such behavior has been assigned to the structural features of the complex, mainly the phenanthroline moiety, that allow a close approach to DNA making operative the nuclease action of HO - radical $[14,17,43]$. It is not straightforward, however, to conclude that this property could be transferred to the nanoparticles. On the other hand, in functionalizing the NPs with the copper complex one should expect an increase of the local concentration of the complex which has the advantage of both increase the generation of HO radical and the positive charge as well. In order to evaluate these assumptions, DNA cleavage assays were performed to investigate the nuclease activity of $\mathrm{Fe}_{3} \mathrm{O}_{4} @ \mathrm{Au} @ \mathrm{Cu}$ and to compare with that presented by $[\mathrm{Cu}(2 \mathrm{CP}-\mathrm{Bz}-$ $\mathrm{SMe})]^{2+}$ in solution. The nuclease activity was followed by relaxation of the supercoiled circular plasmid pBR322 DNA (Form I) into the relaxed (Form II) through DNA agarose gel electrophoresis and the results are shown in Fig. 2. Catalase, D-mannitol and SOD were used as scavengers of reactive oxygen species (ROS) in the cleavage assays aiming to protect DNA from the nuclease activity of $\mathrm{H}_{2} \mathrm{O}_{2}, \mathrm{HO} \cdot$ and $\mathrm{O}_{2} \cdot$ species, respectively.
As reported for the complex in solution [17], no nuclease activity is observed in the absence of the reducing agent AA (Fig. 2A, lane 2). After the addition of AA, however, the band assigned to the supercoiled circular plasmid is barely seen while an intense band corresponding to the relaxed form appears (Fig. 2A, lane 3) indicating the DNA degradation. The non-observation of linear plasmid suggests that the immobilization of the copper complex on the nanoparticle surface reduces its ability to interact at specific positions of the double stranded DNA, which is a necessary condition to produce the double-nicked linear form. In this way, the nuclease activity of $\mathrm{Fe}_{2} \mathrm{O}_{3} @ \mathrm{Au} @ \mathrm{Cu}$ is lower in comparison to the free complex, where there are not mobility restrictions and linear plasmid DNA was observed.

The cleavage assays in the presence of the ROS scavengers (Fig. 2A, lanes 4 to 6) showed that only catalase is able to protect DNA (Fig. 2A, lane 4) meaning $\mathrm{H}_{2} \mathrm{O}_{2}$ is involved in the cleavage mechanism. By accounting that $\mathrm{H}_{2} \mathrm{O}_{2}$ itself does not induce the plasmid DNA degradation, such species is probably taking part in the cleavage process as an intermediate. Also, it cannot be ruled out the presence of $\mathrm{H}_{2} \mathrm{O}_{2}$ as consequence of the autoxidation reaction of AA catalyzed by the copper complex in presence of oxygen. Previous works have indeed shown the enhancement of $\mathrm{H}_{2} \mathrm{O}_{2}$ production within the tumor by the addition of exogenous metal catalyst [44, 45]. For copper complexes containing phenanthroline derivatives, however, the non-protective effect of $\mathrm{D}$ mannitol and SOD has been reported as "false negative" [46, 47], due to the combination of the intercalation ability with the high reactivity of $\mathrm{HO} \cdot$ and $\mathrm{O}_{2} \cdot{ }^{-}$. The results presented in Fig. 2B were obtained in the absence of the reducing agent AA and show the DNA is equally degraded in the presence of $\mathrm{Fe}_{3} \mathrm{O}_{4} @ \mathrm{Au} @ \mathrm{Cu}$ and $\mathrm{H}_{2} \mathrm{O}_{2}$ indicating the oxidative nature of the process. Aiming to further investigate if the activity of $\mathrm{Fe}_{3} \mathrm{O}_{4} @ \mathrm{Au} @ \mathrm{Cu}$ is similar to that proposed for [Cu(2CP-Bz$\mathrm{SMe})]^{2+}$ in solution, EPR measurements were carried out. An aerated aqueous suspension containing $\mathrm{Fe}_{3} \mathrm{O}_{4} @ \mathrm{Au} @ \mathrm{Cu}$ and $\mathrm{H}_{2} \mathrm{O}_{2}$ was kept under stirring for $2 \mathrm{~min}$ followed by the addition of DMPO, which is

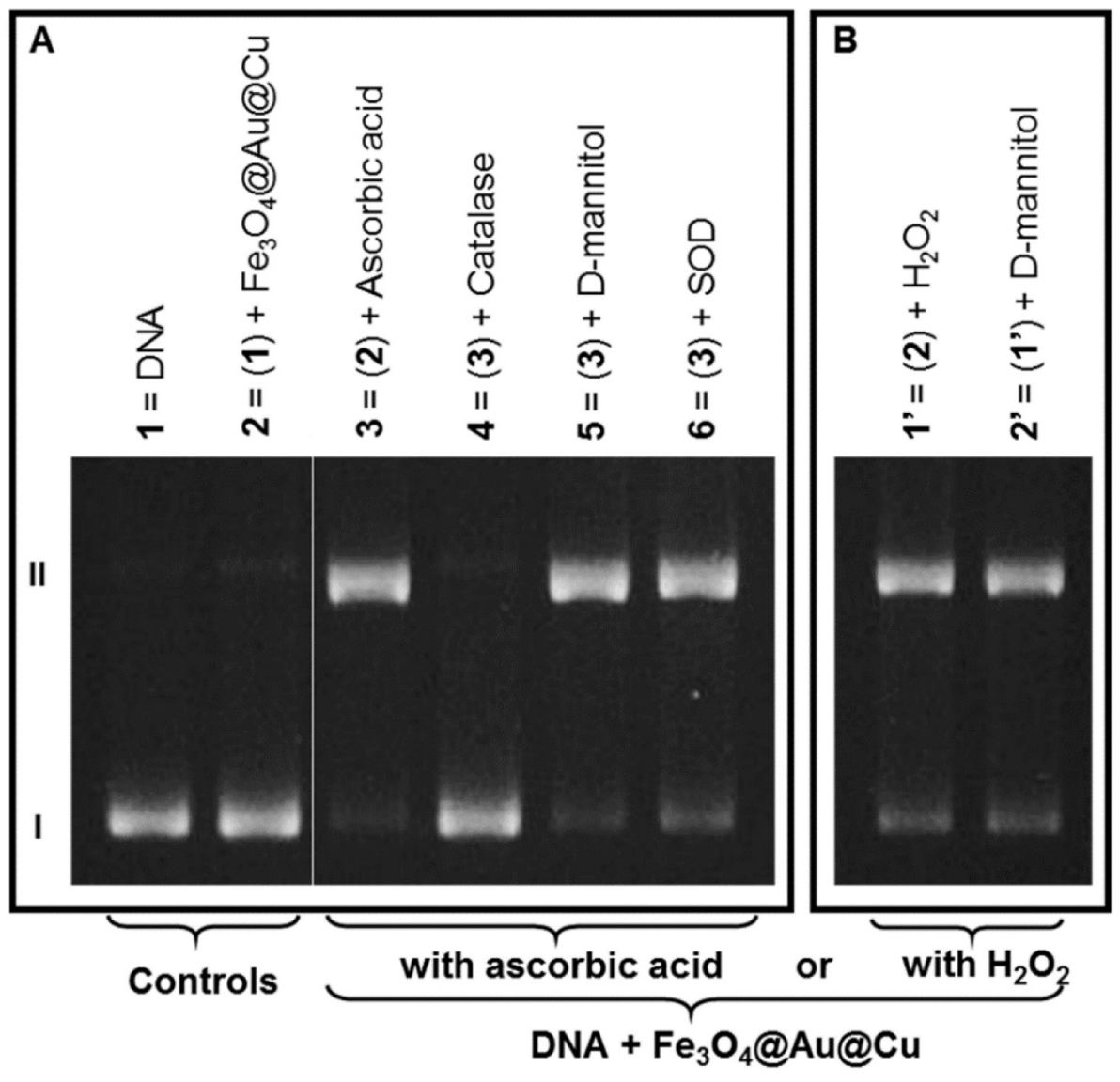

Fig. 2. Cleavage assays of pBR322 plasmid DNA (6.8 ng mL ${ }^{-1}$ ) by $\mathrm{Fe}_{3} \mathrm{O}_{4} @ \mathrm{Au} @ \mathrm{Cu}\left(0.807 \mathrm{mg} \mathrm{mL}^{-1}\right.$ ). A. 1. DNA (control); 2. DNA $+\mathrm{Fe}_{3} \mathrm{O}_{4} @ \mathrm{Au} @ \mathrm{Cu}$; 3. $\mathrm{DNA}+\mathrm{Fe}_{3} \mathrm{O}_{4} @ \mathrm{Au} @ \mathrm{Cu}+\mathrm{AA} ; \quad$ 4. $\mathrm{DNA}+$ $\mathrm{Fe}_{3} \mathrm{O}_{4} @ \mathrm{Au} @ \mathrm{Cu}+\mathrm{AA}+0.1 \mathrm{mg} \mathrm{L}{ }^{-1}$ catalase; 5. $\mathrm{DNA}+\mathrm{Fe}_{3} \mathrm{O}_{4} @ \mathrm{Au} @ \mathrm{Cu}+\mathrm{AA}+50 \mathrm{mM}$ D-mannitol; 6. DNA+ $\mathrm{Fe}_{3} \mathrm{O}_{4} @ \mathrm{Au} @ \mathrm{Cu}+\mathrm{AA}+0.1 \mathrm{mg} \mathrm{L}^{-1} \mathrm{SOD}$. B. 1'. $\mathrm{DNA}+\mathrm{Fe}_{3} \mathrm{O}_{4} @ \mathrm{Au} @ \mathrm{Cu}+3 \mathrm{mM} \mathrm{H}_{2} \mathrm{O}_{2} ; 2^{\prime}$. $\mathrm{DNA}+\mathrm{Fe}_{3} \mathrm{O}_{4} @ \mathrm{Au} @ \mathrm{Cu}+3 \mathrm{mM} \quad \mathrm{H}_{2} \mathrm{O}_{2}+50 \mathrm{mM}$ Dmannitol. $\mathrm{AA}=$ ascorbic acid, $[\mathrm{AA}]=15 \mu \mathrm{M}$. 


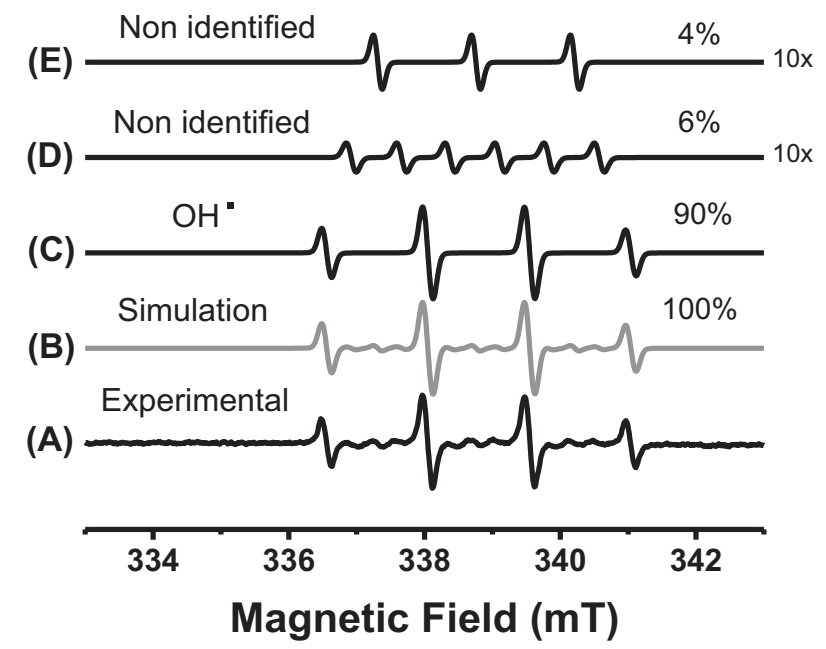

Fig. 3. EPR spectra of $\mathrm{Fe}_{3} \mathrm{O}_{4} @ \mathrm{Au} @ \mathrm{Cu}$ in aerated aqueous solution containing $\mathrm{H}_{2} \mathrm{O}_{2}$ and DMPO. From (A) to (C): experimental, simulation and component 1 identified as DMPO-HO - adduct with $90 \%$ of abundance. (D) and (E) nonidentified components with abundances of $6 \%$ and $4 \%$, respectively (these spectra were magnified 10 times). Spectral simulations were made with the EasySpin program [30]. Measurement conditions: center field $339 \mathrm{mT}$, sweep field $10 \mathrm{mT}$, sweep time $60 \mathrm{~s}$, MW power $20 \mathrm{~mW}$, gain $2.0 \times 10^{3}$, modulation amplitude $0.05 \mathrm{mT}$, modulation frequency $100 \mathrm{kHz}$, time constant: $0.064 \mathrm{~s}$, MW frequency: $9.50390 \mathrm{GHz}$.

known [48] to form long-lived adduct with oxygen-centered radicals. After centrifugation, the reaction mixture was transferred to the quartz cell of the EPR equipment. The acquired spectra are shown in Fig. 3. The hyperfine splitting $\left(\mathrm{a}^{\mathrm{N}}=15.07 \mathrm{G}, \mathrm{a}^{\mathrm{H}}=14.99 \mathrm{G}\right)$ observed in the EPR spectrum of $\mathrm{Fe}_{3} \mathrm{O}_{4} @ \mathrm{Au} @ \mathrm{Cu}$ in solution containing $\mathrm{H}_{2} \mathrm{O}_{2}$ and DMPO indicates the presence of the DMPO-HO - adduct as major component $(90 \%)$ thus virtually discarding the other possible ROS species $\left(\mathrm{O}_{2} \cdot{ }^{-}\right.$or $\left.\mathrm{HOO} \cdot\right)$. The other components (spectra D and E) could be produced by $\mathrm{HO}$ - radical reactions forming secondary species with abundances of $6 \%$ and $4 \%$, respectively, and the following EPR parameters $\mathrm{a}^{\mathrm{N}}=14.65 \mathrm{G}, \mathrm{a}^{\mathrm{H}}=7.44 \mathrm{G}$ and $\mathrm{a}^{\mathrm{N}}=14.65 \mathrm{G}$. Such result hints that the DNA degradation showed in the electrophoresis experiments is essentially due to the $\mathrm{HO} \cdot$ species produced by $\mathrm{Fe}_{3} \mathrm{O}_{4} @ \mathrm{Au} @ \mathrm{Cu}$. Still more relevant is the finding that the radical production property of the $[\mathrm{Cu}(2 \mathrm{CP}-\mathrm{Bz}-\mathrm{SMe})]^{2+}$ ion complex is transferred to the magnetic nanoparticle.

\section{Conclusions}

By means of a modular capping strategy we have produced a magnetic gold-coated $\mathrm{Fe}_{3} \mathrm{O}_{4}$ nanoparticle decorated with a copper complex that presented nuclease activity assigned to the release of hydroxyl radical. SEM-EDS, ICP, TEM and SERS demonstrated the $\mathrm{Fe}_{3} \mathrm{O}_{4}$ nanoparticles were fully recovered by gold and subsequently decorated with $[\mathrm{Cu}(2 \mathrm{CP}-\mathrm{Bz}-\mathrm{SMe})]^{2+}$ through the sulfur atom of the thioether moiety. The magnetic measurements showed the final nanomaterial $\mathrm{Fe}_{3} \mathrm{O}_{4} @ \mathrm{Au} @ \mathrm{Cu}$ is still magnetic although the gold shell and the functionalization with the copper complex have diminished the magnetization due to the mass dilution of the magnetic core. The nuclease assays performed with $\mathrm{Fe}_{3} \mathrm{O}_{4} @ \mathrm{Au} @ \mathrm{Cu}$ indicated the nuclease activity of the nanomaterial toward the plasmid DNA involves an oxidative pathway in which $\mathrm{H}_{2} \mathrm{O}_{2}$ species is involved as intermediate. EPR spectrum of $\mathrm{Fe}_{3} \mathrm{O}_{4} @ \mathrm{Au} @ \mathrm{Cu}$ presented hyperfine splitting ascribed to the $\mathrm{HO}$ - radical, thus indicating this species is the responsible for the DNA degradation observed in the nuclease assays and that the radical production property of the $[\mathrm{Cu}(2 \mathrm{CP}-\mathrm{Bz}-\mathrm{SMe})]^{2+}$ ion complex is transferred to the core-shell gold-coated $\mathrm{Fe}_{3} \mathrm{O}_{4}$ magnetic nanoparticles. So far, at the best of our knowledge, this is the first study reporting the nuclease activity induced by ROS produced by a copper complex immobilized on a gold-coated magnetic nanoparticle.

Abbreviations

2CP-Bz-SMe 1,3-bis((1,10-phenanthrolin-2-yl)oxy)- $N$-(4-(methylthio) benzylidene)propan-2-imine

AA ascorbic acid

clip-phen 1,3-bis((1,10-phenanthrolin-2-yl)oxy)propan-2-amine

DMPO 5,5-dimethyl-1-pyrroline- $N$-oxide

EPR electron paramagnetic resonance

FC field cooled

ICP-OES inductively coupled plasma with optical emission spectroscopy

PBS phosphate buffer solution

ROS reactive oxygen species

SEM-EDS scanning electron microscopy with energy-dispersive X-ray spectroscopy

SERS Surface-Enhanced Raman Scattering

SOD superoxide dismutase

SP surface plasmon

$\mathrm{T}_{\mathrm{B}} \quad$ blocking temperature

TEA triethanolamine

TEM Transmission Electron Microscopy

VSM vibrating sample magnetometry

XRD X-ray powder diffraction

ZFC zero-field cooled

\section{Acknowledgment}

I. Diógenes (\# 307078/2017-5), M. Jafelicci-Jr (\# 309836/2013-1) and D. Abreu are thankful to CNPq and A. Romo (\# 72170429) to CONICYT for the grants. E. Vargas and J. C. Denardin thanks to Basal FB0807. All authors are thankful to CNPq, CAPES, FUNCAP and FONDECYT (\# 11130172) for financial support. The authors are grateful to Professor M. L. A. Temperini for the acquisition of Raman and SERS spectra at São Paulo University.

\section{Statement of contributions}

Maria A. S. Silva and Adolfo I. B. Romo contributed equally to this work; the former with the synthesis and characterization of the magnetic nanoparticles and the latter with the preparation of the copper complex and EPR studies. Miguel Jafelicci-Jr contributed to the synthesis and characterization of the magnetic nanoparticles. Dieric S. Abreu and Tércio F. Paulo were responsible for the acquisition and interpretation of SERS spectra. Otaciro R. Nascimento and Marta S. Carepo were responsible for the acquisition and interpretation of EPR data. Marta S. Carepo contributed with the nuclease assays. Esteban Vargas and Juliano Denardin contributed with the magnetic measurements of the functionalized nanoparticles. Luis Lemus was responsible of the design and synthesis of the complex and revision of the manuscript. Izaura C. N. Diógenes besides being the supervisor of Maria A. S. Silva, Adolfo I. B. Romo and Dieric S. Abreu was responsible for writing the manuscript.

\section{Appendix A. Supplementary data}

Electronic Supplementary Information (ESI) available: [TEM and SEM images, XRD patterns, UV-Vis, SERS, Raman and EDS spectra]. Supplementary data associated with this article can be found in the online version, at https://doi.org/10.1016/j.jinorgbio.2018.06.015.

\section{References}

[1] P. Liu, R. Qin, G. Fu, N. Zheng, J. Am. Chem. Soc. 139 (2017) 2122-2131. 
[2] E.R. Kay, Chem. Eur. J. 22 (2016) 10706-10716.

[3] R. Sensenig, Y. Sapir, C. MacDonald, S. Cohen, B. Polyak, Nanomedicine 7 (2012) 1425-1442.

[4] R. Hao, R. Xing, Z. Xu, Y. Hou, S. Gao, S. Sun, Adv. Mater. 22 (2010) 2729-2742.

[5] A. Senyei, K. Widder, G. Czerlinski, J. Appl. Phys. 49 (1978) 3578-3583.

[6] N. Ma, A. van der Vaart, J. Am. Chem. Soc. 138 (2016) 9951-9958.

[7] T. Moulaei, T. Maehigashi, G.T. Lountos, S. Komeda, D. Watkins, M.P. Stone, L.A. Marky, J.-S. Li, B. Gold, L.D. Williams, Biochemistry 44 (2005) 7458-7468.

[8] D.H. Nguyen-Hackley, E. Ramm, C.M. Taylor, J.K. Joung, P.B. Dervan, C.O. Pabo Biochemistry 43 (2004) 3880-3890.

[9] S. Wang, M. Munde, S. Wang, W.D. Wilson, Biochemistry 50 (2011) 7674-7683.

[10] K. Sato, K. Kawamoto, S. Shimamura, S. Ichikawa, A. Matsuda, Bioorg. Med. Chem. Lett. 26 (2016) 5395-5398.

[11] M. Ahamed, M.J. Akhtar, M.A.M. Khan, H.A. Alhadlaq, A. Alshamsan, Colloids Surf. B 148 (2016) 665-673.

[12] W. Chen, P. Zou, Z. Zhao, X. Chen, X. Fan, R. Vinothkumar, R. Cui, F. Wu, Q. Zhang, G. Liang, J. Ji, Redox Biol. 10 (2016) 78-89.

[13] M. Wehbe, A. Leung, M.J. Abrams, C. Orvig, M. Bally, Dalton Trans. 46 (2017) 10758-10773.

[14] M. Pitié, G. Pratviel, Chem. Rev. 110 (2010) 1018-1059.

[15] E. Gao, Y. Ding, N. Sun, S. Zhang, X. Qiu, Y. Zhan, M. Zhu, Appl. Organomet. Chem. 31 (2017) (e3575-n/a).

[16] C. Acilan, B. Cevatemre, Z. Adiguzel, D. Karakas, E. Ulukaya, N. Ribeiro, I. Correia, J.C. Pessoa, Biochim. Biophys. Acta Gen. Subj. 1861 (2017) 218-234.

[17] A.I.B. Romo, D.S. Abreu, T.F. Paulo, M.S.P. Carepo, E.H.S. Sousa, L. Lemus, C. Aliaga, A.A. Batista, O.R. Nascimento, H.D. Abruña, I.C.N. Diógenes, Chem. Eur. J. 22 (2016) 10081-10089.

[18] N.R. Angel, R.M. Khatib, J. Jenkins, M. Smith, J.M. Rubalcava, B.K. Le, D. Lussier, Z. Chen, F.S. Tham, E.H. Wilson, J.F. Eichler, J. Inorg. Biochem. 166 (2017) 12-25.

19] M. Pitié, B. Donnadieu, B. Meunier, Inorg. Chem. 37 (1998) 3486-3489.

[20] M. Pitié, J.D. Van Horn, D. Brion, C.J. Burrows, B. Meunier, Bioconjug. Chem. 11 (2000) 892-900

21] M. Pitié, C.J. Burrows, B. Meunier, Nucleic Acids Res. 28 (2000) 4856-4864.

[22] P. de Hoog, M. Pitié, G. Amadei, P. Gamez, B. Meunier, R. Kiss, J. Reedijk, J. Biol. Inorg. Chem. 13 (2008) 575-586.

[23] M. Pitié, B. Meunier, Bioconjug. Chem. 9 (1998) 604-611.

[24] B.R. James, R.J.P. Williams, J. Chem. Soc. (1961) 2007-2019.

[25] S. Kim, J.W. Ginsbach, J.Y. Lee, R.L. Peterson, J.J. Liu, M.A. Siegler, A.A. Sarjeant, E.I. Solomon, K.D. Karlin, J. Am. Chem. Soc. 137 (2015) 2867-2874.

[26] S. Kim, J.Y. Lee, R.E. Cowley, J.W. Ginsbach, M.A. Siegler, E.I. Solomon,
K.D. Karlin, J. Am. Chem. Soc. 137 (2015) 2796-2799.

[27] K. Yano, V. Nandwana, G.S. Chaubey, N. Poudyal, S. Kang, H. Arami, J. Griffis, J. Liu, J. Phys. Chem. C 113 (2009) 13088-13091.

[28] S. Sun, H. Zeng, D.B. Robinson, S. Raoux, P.M. Rice, S.X. Wang, G. Li, J. Am. Chem. Soc. 126 (2004) 273-279.

[29] H.G. Bagaria, E.T. Ada, M. Shamsuzzoha, D.E. Nikles, D.T. Johnson, Langmuir 22 (2006) 7732-7737.

[30] S. Stoll, A. Schweiger, J. Magn. Reson. 178 (2006) 42-55.

[31] S.S. Pati, L.H. Singh, E.M. Guimarães, J. Mantilla, J.A.H. Coaquira, A.C. Oliveira, V.K. Sharma, V.K. Garg, J. Alloys Compd. 684 (2016) 68-74.

[32] D. Peddis, F. Orrù, A. Ardu, C. Cannas, A. Musinu, G. Piccaluga, Chem. Mater. 24 (2012) 1062-1071.

[33] R.A. Rader, D.R. McMillin, M.T. Buckner, T.G. Matthews, D.J. Casadonte, R.K. Lengel, S.B. Whittaker, L.M. Darmon, F.E. Lytle, J. Am. Chem. Soc. 103 (1981) 5906-5912.

[34] M.-C. Daniel, D. Astruc, Chem. Rev. 104 (2004) 293-346.

[35] C.A. Szafranski, W. Tanner, P.E. Laibinis, R.L. Garrell, Langmuir 14 (1998) 3570-3579.

[36] T.G. Lee, K. Kim, M.S. Kim, J. Raman Spectrosc. 22 (1991) 339-344.

[37] G.A. Bowmaker, B.C. Dobson, J. Chem. Soc. Dalton Trans. (1981) 267-270.

[38] H. Sellers, A. Ulman, Y. Shnidman, J.E. Eilers, J. Am. Chem. Soc. 115 (1993) 9389-9401.

[39] I.C.N. Diógenes, I.M.M. Carvalho, E. Longhnotti, L.G.F. Lopes, M.L.A. Temperini, G.F.S. Andrade, I.S. Moreira, J. Electroanal. Chem. 605 (2007) 1-7.

[40] T.F. Paulo, H.D. Abruña, I.C.N. Diógenes, Langmuir 28 (2012) 17825-17831.

[41] T.F. Paulo, R.A. Ando, I.C.N. Diógenes, M.L.A. Temperini, J. Phys. Chem. C 117 (2013) 6275-6283.

[42] S. Joseph, H. Noller, Methods Enzymol. 318 (2000) 175-190.

[43] C.H. Chen, D.S. Sigman, Proc. Natl. Acad. Sci. U. S. A. 83 (1986) 7147-7151.

[44] A. Tovmasyan, R.S. Sampaio, M.-K. Boss, J.C. Bueno-Janice, B.H. Bader, M. Thomas, J.S. Rebouças, M. Orr, J.D. Chandler, Y.M. Go, et al., Free Radic. Biol. Med. 89 (2015) 1231-1247.

[45] M.K. Evans, A. Tovmasyan, I. Batinic-Haberle, G.R. Devi, Free Radic. Biol. Med. 68 (2014) 302-314.

[46] S. Goldstein, G. Czapski, J. Free Radic. Biol. Med. 1 (1985) 373-380.

[47] O.I. Aruoma, B. Halliwell, E. Gajewski, M. Dizdaroglu, Biochem. J. 273 (1991) $601-604$

[48] C.L. Hawkins, M.J. Davies, Biochim. Biophys. Acta Gen. Subj. 1840 (2014) 708-721 